\title{
VAKSINASI MASAL COVID-19 DI PELABUHAN LEMBAR LOMBOK BARAT
}

\author{
Desi Rofita1), Evi Diliana Rospia²), Dwi Kartika Cahyaningtyas²), Catur Esty Pamungkas'), \\ Aulia Amini ${ }^{4}$,Siti Mardiyah WD ${ }^{4}$, Biantari Alika Maharani ${ }^{3)}$
}

\begin{abstract}
1)Program Studi S1 Kebidanan, Universitas Muhammadiyah Mataram, Mataram, NTB, Indonesia ${ }^{2)}$ Program Studi Pendidikan Profesi Bidan Program Profesi, Universitas Muhammadiyah Mataram, Mataram, NTB, Indonesia

4)Program Studi S1 Kebidanan, Universitas Muhammadiyah Mataram, Mataram, NTB, Indonesia

${ }^{5)}$ Program Studi D3 Kebidanan, Universitas Muhammadiyah Mataram, Mataram, NTB, Indonesia
\end{abstract}

\author{
Corresponding author : Desi Rofita \\ E-mail : desirofita21@gmail.com
}

Diterima 15 November 2021, Disetujui 27 November 2021

\begin{abstract}
ABSTRAK
WHO (World Health Organization) secara resmi mendeklarasikan virus corona (Covid-19) sebagai pandemi. Virus Covid-19 menyebabkan gejala seperti demam dan batuk, dan kebanyakan bisa sembuh dalam beberapa minggu. Tapi bagi sebagian orang yang berisiko tinggi (kelompok lanjut usia dan orang dengan masalah kesehatan menahun, seperti penyakit jantung, tekanan darah tinggi, atau diabetes), virus corona dapat menyebabkan masalah kesehatan yang serius. Ada dua jalur utama penularan COVID-19, yakni penularan droplet pernapasan dan penularan kontak dekat. Dalam rangka penanggulangan pandemi COVID-19 tidak hanya dilaksanakan dari sisi penerapan protokol kesehatan, namun juga intervensi dengan vaksinasi sebagai bagian dari upaya pencegahan dan Pengendalian COVID-19. Kegiatan vaksinasi masal ini bertujuan agar dapat terbentuk herd immunity (kekebalan kelompok) dan berkurangnya angka kematian akibat COVID-19 pada masyarakat.Jenis vaksin yang digunakan pada kegiatan vaksinasi masal ini adalah Moderna. Jumlah responden yang mengikuti kegiatan ini sebanyak 1.581 orang. Hasil pengabdian didapatkan bahwa jumlah yang melakukan vaksinasi sebanyak 1.581 orang yang terdiri remaja sebanyak 60 orang dewasa sebanyak 1497 orang dan lansia sebanyak 24 orang, diberikan vaksin sebanyak 1.536 orang, ditunda sebanyak 45 orang.
\end{abstract}

Kata kunci: vaksinasi; covid-19; komunitas.

\begin{abstract}
WHO (World Health Organization) has officially declared the coronavirus (Covid-19) as a pandemic. The Covid-19 virus causes symptoms such as fever and cough, and most recover within a few weeks. But for some people who are at high risk (the elderly and people with chronic health problems, such as heart disease, high blood pressure, or diabetes), the coronavirus can cause serious health problems. There are two main routes of transmission of COVID-19, namely respiratory droplet transmission and close contact transmission. In the context of dealing with the COVID-19 pandemic, it is not only implemented in terms of implementing health protocols but also interventions with vaccinations as part of efforts to prevent and control COVID-19. This mass vaccination activity aims to form herd immunity and reduce the mortality rate due to COVID-19 in the community. The type of vaccine used in this mass vaccination activity is Moderna. The number of respondents who participated in this activity was 1,581 people. The results of the service found that the number of people who registered for Pcare was 1,581 people, consisting of 60 teenagers, 1497 adults, and 24 elderly people, 1,536 people were given the vaccine, 45 people were delayed.
\end{abstract}

Keywords: vaccination; covid-19; community.

\section{PENDAHULUAN}

WHO (World Health Organization)

secara resmi mendeklarasikan virus corona (COVID-19) sebagai pandemi pada tanggal 9 Maret 2020. Pandemi bermakna penyebaran penyakit yang meluas (World Health Organization, 2020). Patogen paling umum dari penyakit menular baru adalah virus, yang terbaru adalah COVID-19. SARS dan COVID-
19 memiliki pengaruh serius pada manusia (Qu, Cao and Chen, 2021).Virus corona menyebabkan gejala yang ringan atau sedang, seperti demam dan batuk, dan kebanyakan bisa sembuh dalam beberapa minggu. Tapi bagi sebagian orang yang berisiko tinggi (kelompok lanjut usia dan orang dengan masalah kesehatan menahun, seperti penyakit jantung, tekanan darah tinggi, 
atau diabetes), virus corona dapat menyebabkan masalah kesehatan yang serius (World Health Organization, 2020).

Sumber infeksi ini terutama dari pasien COVID-19, mereka dengan infeksi ringan dan tanpa gejala juga dapat menjadi sumber infeksi (Qu, Cao and Chen, 2021). Ada dua jalur utama penularan COVID-19, yakni penularan droplet pernapasan dan penularan kontak dekat(Qu, Cao and Chen, 2021). Virus COVID-19 menyebar terutama melalui tetesan air liur atau keluarnya cairan dari hidung ketika orang yang terinfeksi batuk atau bersin, jadi penting untuk mempraktikkan etika pernapasan (misalnya, dengan batuk ke siku yang tertekuk) (World Health Organization, 2020).

Dalam rangka penanggulangan pandemi COVID-19 tidak hanya dilaksanakan dari sisi penerapan protokol kesehatan, namun juga intervensi dengan vaksinasi sebagai bagian dari upaya pencegahan dan Pengendalian COVID-19. Berdasarkan rekomendasi dari Komite Penasihat Ahli Imunisasi Nasional (Indonesian Technology Advisory Group on Immunization) tahun 2020, untuk dapat mengendalikan pandemi COVID-19 di masyarakat secara cepat yaitu dengan meningkatkan kekebalan individu dan kelompok sehingga dapat menurunkan angka kesakitan dan kematian, serta mendukung produktifitas ekonomi dan sosial, pemberian vaksinasi COVID-19 dilakukan dengan strategi yang tepat pada kelompok sasaran prioritas.

Selain itu pemerintah membuat berbagai kebijakan guna melindungi masyarakat dari penularan dan dampak COVID-19 mulai dari pembatasan sosial berskala besar termasuk pembatasan sekolah, tempat kerja, tempat peribadatan, tempat umum dan transportasi, pemberian bantuan sosial, pemberian insentif bagi tenaga kesehatan, kebijakan masker untuk semua dan kebijakan penerapan protokol kesehatan di berbagai tempat yang terus digaungkan selagi menanti vaksin.

Pemerintah Indonesia dan juga negara negara di dunia tengah berupaya mengembangkan dan menghadirkan Vaksin COVID-19 serta merencanakan pelaksanaan imunisasi untuk warganya. Vaksin tidak hanya melindungi individu namun juga memberikan perlindungan bagi orang orang yang tidak dapat diimunisasi' contohnya pada usia tertentu maupun orang dengan penyakit tertentu. Vaksin tidak menimbulkan penyakit. Vaksin yang sudah dipakai di masyarakat sudah dijamin keamanannya dan umumnya tidak menimbulkan reaksi simpang (efek samping) yang berat (Iskak et al., 2021).

Adapun sesuai dengan standar Badan Kesehatan Dunia (WHO), setiap penduduk akan mengikuti dua kali penyuntikan atau membutuhkan dua dosis vaksin. Ada tujuh jenis vaksin COVID-19 yang dapat digunakan dalam proses vaksinasi di Indonesia. Ketujuh vaksin tersebut diproduksi oleh Bio Farma, Astra Zaneca, Shinopharm, Moderna, Novavax Inc, Pfizer Inc and BioNtech dan Sinovac Biotech (Iskak et al., 2021).

\section{METODE}

Metode kegiatan pengabdian masyarakat ini melibatkan Dinas Kesehatan Provinsi NTB dan petugas Kementerian Kelautan dan Perikanan (KKP) Pelabuhan Lembar. Lokasi vaksinasi masal yaitu dipelabuhan lembar. Sasaran pemberian vaksin adalah masyarakat yang akan melakukan penyebrangan keluar wilayah NTB melalui jalur laut. Merujuk dari peraturan pemerintah tentang pemberlakukan persyaratan harus vaksinasi untuk jalur transportasi maka hal ini menjadi alasan pemelihan tempat pelabuhan lembar. Mekanisme/alur pelayanan pemberian vaksin yaitu:

Meja 1 (petugas pendaftaran/verifikasi)

1. Petugas memanggil sasaran penerima vaksinasi kemeja 1 sesuai dengan nomor urutan kedatangan

2. Petugas memastikan sasaran menunjukkan nomortiket elektronik (eticket) dan/atau KTP untuk dilakukan verifikasi sesuai dengan tanggal pelayanan vaksinasi yang telah ditentukan.

3. Verifikasi data dilakukan dengan menggunakan aplikasi Pcare Vaksinasi (pada komputer/laptop/HP) atau secara manual yaitudengan menggunakan daftar data sasaran yang diperoleh melalui aplikasi Pcare Vaksinasi yang sudah disiapkan sebelum hari $H$ pelayanan (datasasaran pada aplikasi Pcare diunduh kemudian dicetak/print).

Meja 2 (petugas pendaftaran/verifikasi)

1. Petugas kesehatan melakukan anamnesa untuk melihat kondisi kesehatan dan mengidentifikasi kondisi penyerta (komorbid) serta melakukan pemeriksaan fisik sederhana. Pemeriksaan meliputi suhu tubuh dan tekanan darah.

2. Vaksinasi COVID-19 tidak diberikan pada sasaran yang memiliki riwayat konfirmasi COVID-19, wanita hamil, menyusui, usia di bawah 18 tahun dan 
beberapa kondisi komorbid yang telah disebutkan dalam format skrining.

3. Data skrining tiap sasaran langsung diinput keaplikasi Pcare Vaksinasi oleh petugas menggunakan komputer/laptop/HP. Bila tidak memungkinkan untuk menginput data langsung kedalam aplikasi (misalnya akses internet tidak adaatau sarana tidak tersedia), maka hasil skriningdicatat di dalam format skrining untukkemudian diinput ke dalam aplikasi setelah tersedia koneksi internet

4. Berdasarkandata yang dimasukkan oleh petugas,aplikasi akan mengeluarkan rekomendasi hasil skrining berupa: sasaran layak divaksinasi (lanjut), ditunda atau tidak diberikan. Jika diputuskan pelaksanaan vaksinasi harus ditunda, maka petugas menyampaikan kepada sasaran bahwa akan ada notifikasi ulang melalui sms blast atau melalui aplikasi peduli lindungi untuk melakukan registrasi ulang dan menentukan jadwal pengganti pelaksanaan vaksinasi.

5. Dilanjutkan dengan pengisian keputusan hasil skrining oleh Petugas di dalam aplikasi Pcare Vaksinasi

a. Ketika pada saat skrining dideteksi ada penyakit tidak menular atau dicurigai adanya infeksi COVID-19 maka pasien dirujuk untuk mendapat pemeriksaan lebih lanjut

b. Sasaran yang dinyatakan sehat diminta untuk melanjutkan ke Meja 3.

c. Petugas memberikan penjelasan singkat tentangvaksin yang akan diberikan, manfaat dan reaksisimpang (KIPI) yang mungkin akan terjadi dan upaya.

Meja 3 (vaksinator)

1. Sasaran duduk dalam posisi yang nyaman

2. Untuk vaksin mutidosis petugas menuliskantanggal dan jam dibukanya vial vaksin denganpulpen/spidol di label pada vial vaksin

3. Petugas memberikan vaksinasi secara intramuskular sesuai prinsip penyuntikan aman

4. Petugas menuliskan nama sasaran, NIK, namavaksin dan nomor batch vaksin pada sebuah memo. Memo diberikan kepada sasaran untuk diserahkankepada petugas di Meja 4.

5. Selesai penyuntikan, petugas meminta dan mengarahkan sasaran untuk ke Meja 4 dan menunggu selama 30 menit.

Meja 4 (petugas pencatatan)

1. Petugas menerima memo yang diberikan oleh petugas Meja 3
2. Petugas memasukkan hasil vaksinasi yaitu jenisvaksin dan nomor batch vaksin yang diterima masing-masing sasaran ke dalam aplikasi Pcare Vaksinasi.

3. Bila tidak memungkinkan untuk menginput data langsung ke dalam aplikasi (misalnya akses internet tidak ada atau sarana tidak tersedia), maka hasil pelayanan dicatat di dalam format pencatatan manual yang sudah disiapkan sebelum hari $\mathrm{H}$ pelayanan untuk kemudian diinput ke dalam aplikasi setelah tersedia koneksi internet.

4. Petugas memberikan kartu vaksinasi, manual dan/atau elektronik, serta penanda kepada sasaran yang telah mendapat vaksinasi. Petugas dapat mencetak kartu vaksinasi elektronik melalui aplikasi Pcare Vaksinasi. Kartu tersebut ditandatangi dan diberi stempel lalu diberikan kepada sasaran sebagai bukti bahwa sasaran telah diberikan vaksinasi.

5. Petugas mempersilakan penerima vaksinasi untuk menunggu selama 30 menit di ruang observasi dan diberikan penyuluhan dan media KIE tentang pencegahan COVID-19 melalui 3M dan vaksinasi COVID-19.

\section{HASIL DAN PEMBAHASAN \\ Hasil}

Kegiatan pengabdian masyarakat dilaksanakan mulai pada tanggal 05 Juli 2021 pukul 08.00 WITA yang diselenggrakan di Pelabuhan Lembar Kabupaten Lombok Barat. Pelaksanaan pengabdian tetap memperhatikan protokol kesehatan selama pandemi covid19. Protokol kesehatan yang dijalankan yaitu memakai masker, mencuci tangan sebelum masuk keruang vaksinasi, menjaga jarak, membatasi jumlah kerumunan. Adapun tahapan-tahapan dalam kegiatan ini yaitu sebagai berikut:

\section{Perencanaan}

a. Pelatihan vaksninator yang diadakan oleh Dinas Kesehatan Provinvi NTB. Pada pelatihan ini juga menjelaskan rangkaian kegiatan secara teknis pelaksanaan vaksinasi. Pada pembekalan ini juga menjelaskan rangkaian kegiatan secara teknis pelaksanaan

b. Persiapan kegiatan pengabdian tanggal, lokasi pengabdian dan alat dan bahan yang dibutuhkan. 

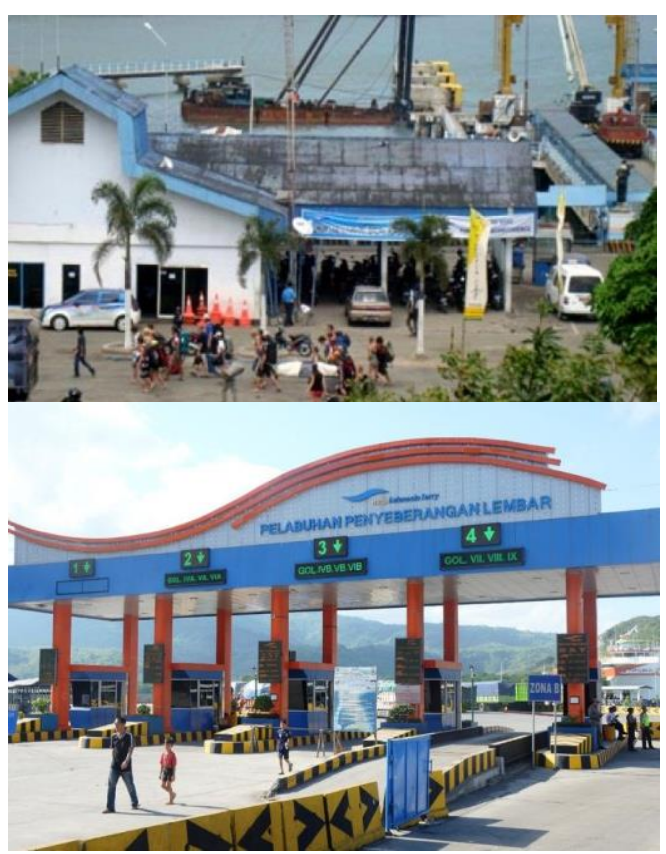

Gambar 1. Lokasi Pengabdian Masyarakat

\section{Tindakan}

Mekanisme/alur pelayanan pemberian vaksin yaitu:

Meja 1 (Petugas pendaftaran/verifikasi)

Petugas memanggil sasaran penerima vaksinasi dan memastikan sasaran menunjukkan KTP untuk dilakukan verifikasi sesuai dengan tanggal pelayanan vaksinasi.

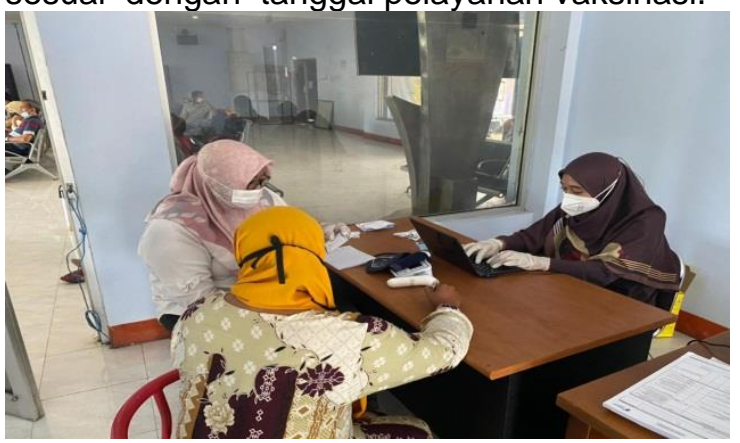

Gambar 2. Petugas pendaftaran/verifikasi

Meja 2 (Input Data Pcare/verifikasi)

Petugas kesehatan melakukan anamnesa untuk melihat kondisi kesehatan dan mengidentifikasi kondisi penyerta (komorbid) serta melakukan pemeriksaan suhu tubuh dan tekanan darah serta menginput data peserta kedalam aplikasi Pcare.

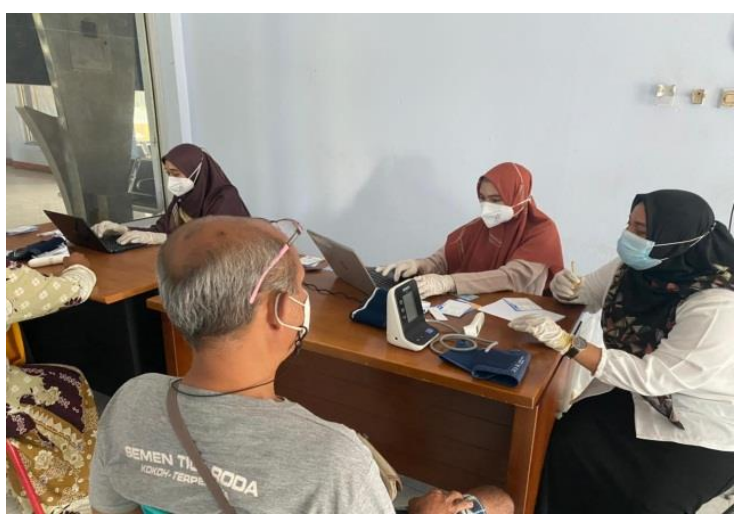

Gambar 3. Petugas menginput data/ verifikasi

\section{Meja 3 (vaksinator)}

Petugas memberikan vaksinasi secara intramuskular sesuai prinsip penyuntikan aman dan petugas menuliskan nama sasaran, $\mathrm{NIK}$, nama vaksin dan nomor batch vaksin pada sebuah memo

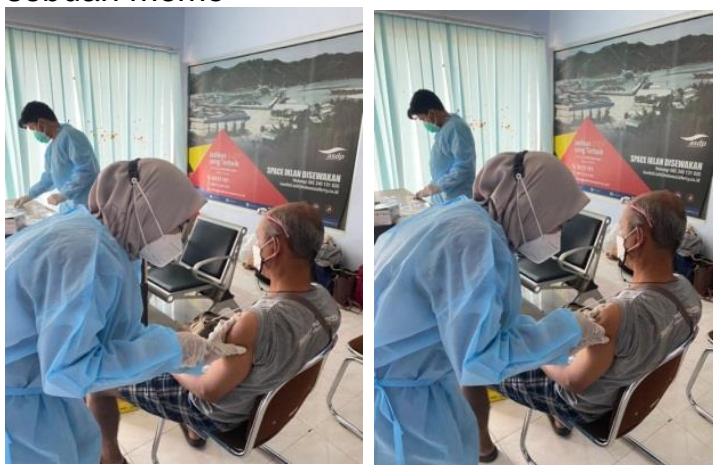

Gambar 4. Petugas memberikan vaksi

\section{Meja 4 (petugas pencatatan)}

Petugas mempersilakan penerima vaksinasi untuk menunggu selama 30 menit di ruang observasi dan diberikan penyuluhan dan media KIE tentang pencegahan COVID-19 melalui 3M dan vaksinasi COVID-19. Petugas memberikan kartu vaksin

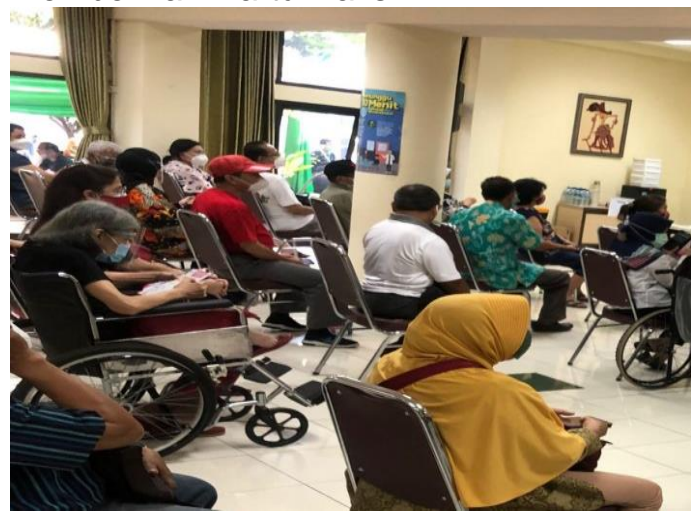

Hasil pengabdian didapatkan bahwa jumlah sasaran vaksinasi sebanyak 1.581 orang yang terdiri remaja sebanyak 60 orang dewasa sebanyak 1497 orang dan lansia sebanyak 24 orang, diberikan vaksin sebanyak 1.536 orang, ditunda sebanyak 45 orang. 


\section{Pembahasan}

Coronavirus atau virus corona merupakan keluarga besar virus yang menyebabkan infeksi saluran pernapasan atas ringan hingga sedang, seperti penyakit flu. Banyak orang terinfeksi virus ini, setidaknya satu kali dalam hidupnya. Pemberian vaksinasi didasarkan Keputusan Direktur Jenderal Pencegahan dan Pengendalian Penyakit tentang Petunjuk tekhnis Pelaksanaan Vaknisasi dalam Rangka Penanggulangan Pandemo Corona Virus Disease 2019 (Kemenkes RI, 2021). Salah satu cara untuk mengontrol dan mencegah transmisi virus Corona dilakukan dengan cara pemberian vaksin (Qu, Cao dan Chen, 2021). Vaksin telah terbukti berhasil digunakan sebagai profilaksis maupun terapiutik (Myint AND Jones, 2020).

Oleh karena itu, perlu segera dilakukan intervensi tidak hanya dari sisi penerapan protokol kesehatan namun juga diperlukan intervensi lain yang lebih efektik untuk memutuskan mata rantai penularan penyakit, yaitu melalupi upaya vaksinasi. Vaksinasi Covid-19 bertujuan utnuk mengurangi transmisi/penularan Covid-19, menurunkan angka kesakitan dan kematian akibat Covid-19, mencapai kekebalan kelompok dimasyarakat (herd immunity) dan melindungi masyarakat dari Covid-19 agar tetap produksif secara social dan ekonomi. Kekebalan kelompok hanya dapat terbentuk apabila cakupan vaksinasi tinggi dan merata keseluruh wilayah (Kemenekes RI, 2021).

Ada beberapa jenis vaksin yang sedang dikembangkan. Semuanya mengandung zat yang dapat meningkatkan sistem kekebalan yang membuat tubuh mengenali dan melawan virus yang menyebabkan virus corona. Terkadang, proses ini menimbulkan gejala seperti demam ringan. Gejala ini normal dan sebagai tanda bahwa tubuh sedang membangun perlindungan terhadap virus penyebab Covid-19 (Haque, M. G., et al, 2020).

Vaksin yang digunakan di Indonesia saat ini yaitu Sinovac. Vaksin Covid-19 Sinovac adalah vaksin asal China berjenis virus mati yang kini sudah didatangakan Indonesia sebanyak 1,2 juta vaksin. Vaksin Covid-19 Sinovac dari China yang tergolong vaksin virus mati, sudah mendapat izin penggunaan darurat atau emergency use authorization (EUA) vaksin virus corona (Covid-19) dari Badan Pengawas Obat dan Makanan (BPOM) (Affandi, et al, 2020).

Orang yang Sudah Tertular dan Sembuh dari COVID-19 Perlu Divaksinasi Ini karena risiko kesehatan yang para terkait COVID-19 dan fakta bahwa infeksi ulang
COVID-19 sangat mungkin terjadi. Vaksin harus diberikan pada seseorang yang pernah terinfeksi COVID-19. Saat ini, para ahli belum mengetahui sampai kapan seseorang terlindungi dari sakit lagi setelah sembuh dari COVID-19. Kekebalan tubuh yang didapatkan seseorang dari infeksi (kekebalan alami), bervariasi pada setiap orang.

\section{SIMPULAN DAN SARAN}

Kegiatan Pemberian vaksinasi COVID-19 merupakan upaya pencegahan penyakit COVID-19 dalam memutus penyebaran penyakit COVID-19. Kegiatan Pengabdian masyarakat ini sebagai kegiatan yang mendukung upaya kebijakan pemerintah dalam mengurangi resiko penularan penyakit COVID-19. Jumlah yang melakukan sasaran vaksinasi sebanyak 1.581 orang yang terdiri remaja sebanyak 60 orang dewasa sebanyak 1497 orang dan lansia sebanyak 24 orang, diberikan vaksin sebanyak 1.536 orang, ditunda sebanyak 45 orang. Pemberian vaksinasi diharapkan tidak hanya melibatkan fasilitas kesehatan melainkan perlu adanya kerja sama stakeholder antara intansi pelayanan kesehatan, dinas kesehatan setempat, dan instansi pendidikan yang memiliki fakultas kesehatan/kedokteran guna mensukseskan program pemerintah untuk membentuk herd immunity (kekebalan kelompok) dan menurunkan angka kematian akibat COVID-19 pada masyarakat.

\section{UCAPAN TERIMAKASIH}

Tim penulis mengucapkan terima kasih kepada Dinas Kesehatan Provinsi, petugas Kementerian Kelautan dan Perikanan (KKP) Pelabuhan Lembar dan Lembaga Penelitian dan Pengabdian Masyarakat Universitas Muhammadiya dan Mitra Pengabdian Masyarakat yang telah mendukung dan memfasilitasi kegiatan pengabdian sehingga berjalan dengan lancar.

\section{DAFTAR RUJUKAN}

Affandi, A., Sarwani, A. S., Erlangga, H., Siagian, A. O., Purwanto, A., Effendy, A. A,\& Wahyitno, C. D. M. (2020). Optimization of MSMEs Empowerment in Facing Competition in the Global Market during the COVID-19 Pandemic Time. Systematic Reviews in Pharmacy, 11(11), 1506-1515.

Haque, M. G., Munawaroh, M., \& Sunarsi, D. (2020). Analysis of SMEs Culinary Marketing Strategy During Covid 19 Pancemic: A Study at "Sate Bebek Cilegon" Resto in Cilegon, Banten. International Journal of Education, 
Information Technology, and Others, 3(2), 447-451.

Iskak, I., Rusydi, M. Z., Hutauruk, R., Chakim, S., \& Ahmad, W. R. (2021). Meningkatkan Kesadaran Masyarakat Tentang Pentingnya Vaksinasi Di Masjid Al - Ikhlas, Jakarta Barat. Jurnal PADMA: Pengabdian Dharma Masyarakat, 1(3), 2021.

http://openjournal.unpam.ac.id/index.php /JPDM/article/view/11431

Ma'rifat, L. (2021) 'Faktor-faktor Penerimaan Vaksin Covid-19 pada Masyarakat Kota Salatiga Ditinjau dari Teori Health Belief Model', eprints.undip, 19, p. 6.

Myint, A.and Jones, T. (2020) 'Possible treatment of Covid-19 with a therapeutic vaccine', Veterinary Record, 186(13), p. 419. doi: 10.1136/vr.m1302.

Priyoto (2014) Teori Sikap dan Prilaku dalam Kesehatan. Yogyakarta: Nuha Medika.

Qu, J.-M., Cao, B. and Chen, R.-C. (2021) COVID-19 The Essentials of Prevention and Treatment, Covid-19. United Kingdom: Elseiver. doi: 10.1016/b9780-12-824003-8.09994-0.

World Health Organization, (WHO) (2020) Coronavirus, World Health Organization. Available at: https://www.who.int/healthtopics/coronavirus\#tab=tab 1 